Article

\title{
Keening the Dead: Ancient History or a Ritual for Today?
}

\author{
Mary Mc Laughlin
}

Irish World Academy of Music and Dance, University of Limerick, V94 T9PX Limerick, Ireland; mary.mclaughlin@ul.ie

Received: 6 March 2019; Accepted: 24 March 2019; Published: 29 March 2019

check for updates

\begin{abstract}
In his 1909 work 'Rites De Passage', Arnold van Gennep acknowledges that a ritual often contains 'rites within rites'. So, it was with the ancient ritual of the Irish wake, at the center of which was another ritual, that of the keen, the Irish funeral lament. The past tense is used tentatively here, as in this article the author explores the resilience of the ritual and how, rather than becoming extinct, the keen seems to spend periods of time underground before erupting again in a new form, attuning itself to a more contemporaneous social situation. Drawing on ethnographic and bibliographic research undertaken between 2010 and 2018, the author traces some of the history of the keen within the ritual of the Irish wake and funeral and gives instances of how it is being reconfigured in the 21st century. This continuation of the ritual, albeit in a new format, seems to speak to a deep emotional and spiritual need that may not be satisfied by more conventional religion in Ireland. Finally, the author considers the keen's relevance and place in Irish society today.
\end{abstract}

Keywords: keen; wake; funeral; Ireland; tradition; custom; culture; history; chant

\section{Introduction}

Arnold van Gennep theorized that rituals often contain rites within other rites (van Gennep 1909, p. 23). This insight is highly relevant to the subject of this essay, which examines the ancient Irish funeral lament known as the keen, within its traditional context of the greater ritual of the Irish wake. The term 'keen' is derived from the title of the mourning ritual for the dead, caoineadh na marbh (lament for the dead). The Anglicized word 'keen', from the Irish word caoine or caoineadh, meaning vocalized cry, has passed into common parlance as a descriptor for the instinctive raw cry that is often the first reaction of the bereaved to death. However, in Ireland, it has another deeper layer of meaning, based on a centuries-old ritual of which remnants still remain today. Although primal instinct may be at its core, the keen was a sacred improvised chant that evolved over many centuries. It was traditionally sung over a corpse and was intrinsic to the ritual of the wake and funeral obsequies. Etic observers did not understand the significance of either the Irish wake or the place of the keen within it and were inclined to dismiss both as heathenish and unacceptable to Christian society.

Brendán Ó Madagáin explains that there was a strong sense of protectiveness around the keen, which made the peasantry unwilling to perform it outside its context (Ó Madagáin 1982, in Ó Driscoll, p. 311). As a result, there are few available examples of contemporaneous keens. Those that were recorded by collectors in the 1950s include keens sung by Kitty Gallagher (Ní Gallchóir 1951, tr. 27/28); Bridget Mullin (1957, tr. 20), and the anonymous Aran Female Singer (1957, tr. 19). It must be noted, however, that these were remembered keens rather than the improvised performance, which is at the heart of the ritual.

Although set songs were sometimes used as mourning songs, including the body of religious keens that have been preserved within the Irish song and literary traditions, that corpus is not the subject of this essay. The traditional keen referenced in this essay is of an improvisational nature, 
constructed around a tri-partite structure (Ó Madagáin 1982, pp. 312-13), and reflects the life and passing of the individual who has just died. Patrick Weston Joyce described this spontaneous form of keening performed on the occasion of a death, within the context of a wake, as 'a lament in Irish — partly extempore, partly prepared-delivered in a kind of plaintive recitative' (Joyce 1873, p. 59).

The practice of keening in Ireland came in for severe censure from the Roman Catholic Church (given that the keen was predominantly practiced by Roman Catholics). Church Synods from 1614 onwards voiced clerical opposition to wakes with increasing vehemence (Ó Crualaoich 1999, pp. 174-75) so that by the middle of the nineteenth century the custom had been noticeably watered down. It is interesting that, as the Roman Catholic Church has lost its once tight grip on Irish society over the last 20 years, the idea of 'waking the dead' is experiencing a resurgence in Ireland, particularly in rural communities. This author has heard rumors of the keen being sung in island communities to this day, but the nature of the ritual is sacred, private, and shrouded in secrecy (for the historical reasons outlined below), making it difficult to collect evidence of its performance. Based on empirical evidence from contemporary Irish writer Kevin Toolis and a credible witness whom this author interviewed (both of whom are referenced below), it seems clear that its reverberations were still being felt at the beginning of the twenty first century. To understand the significance of the keen, though, it is necessary to first understand its context-that of the 'wake'.

\section{Brief History of the Irish Wake}

The need to express the grief of bereavement in communal crying or wailing is not unique to Ireland; it is common to many cultures and contexts. In Ireland though, it took its own form of a ritualized vocal musical response. In an 1830s article, entitled 'The Irish Funeral Cry' the writer, known as O'G, cited the following report of the Irish keen by the twelfth century chronicler Giraldus Cambrensis:

... the Irish then musically expressed their griefs; that is they applied the musical art, in which they excelled all others, to the orderly celebration of funeral obsequies, by dividing the mourners into two bodies, each alternately singing their part, and the whole at times joining in full chorus. The body of the deceased, dressed in grave clothes, and ornamented with flowers, was placed on a bier, or some elevated spot. The relations and keeners (singing mourners) then ranged themselves in two divisions, one at the head and the other at the foot of the corpse. The bards and croteries had before prepared the funeral caoinan ... ( $\mathrm{O}^{\prime} \mathrm{G}$ 1833, p. 242)

Over centuries, this mourning lament came to reflect a blend of pagan and Christian beliefs and was embedded in the wake and funeral obsequies.

The Oxford English Dictionary gives the meaning of the noun 'wake', as the following: 'A watch or vigil held beside the body of someone who has died, sometimes accompanied by ritual observances.' The origin of the word is given as 'Old English (recorded only in the past tense wōc), also partly from the weak verb wacian 'remain awake, hold a vigil', of Germanic origin ... ' (OED 2019).

The custom of 'waking the dead' is ancient and there are extant accounts of wakes throughout Europe, reaching back at least a millennium (Ó Súilleabháin 1967, p. 12). Samuel Hall, writing in 1841 , commented on the very real danger of a body being stolen by unethical scientists for medical experimentation (Hall 1841, vol. 1. p. 232; Ó Súilleabháin 1967, p. 172). It is further believed that ancient funerary rituals included a protective element. James Mooney notes that there was a terror of supernatural forces, which were believed to be unleashed at the time of death, and that one of the purposes of the wake was to protect the body from "the attacks of evil spirits until it was safely disposed of..." (Mooney 1888, p. 270)ํ․ Mooney (ibid., p. 256) and Daithí Ó hÓgáin (2002, p. 3) draw

1 See also Annie Ross (Ross 1982, pp. 205-6) who suggests that the fear of the Otherworld propelled the wish for magical protection as displayed by early Britons-a belief that very likely was also held in Ireland. 
parallels with ancient Egyptian burial rites, such as the depositing of grave goods and funerary feasts at the hills and dolmens that were chosen as final repositories. The idea of the 'funerary feast' is, to this day, an essential element of the wake ritual, which fulfills not only the pragmatic function of keeping mourners awake, but also affirms community. In addition, the act of sharing food is a habitual element of ritual and usually has a symbolic significance. Food, at its most basic level, is life-affirming and can offer comfort in a time of great distress. Not only food, but drink, tobacco, and snuff were all part of the traditional Irish ritual meal offered to visitors, at least until the second part of the twentieth century. Writer Kevin Toolis, for example, describes his experience of attending a wake as a fifteen-year-old in the 1960s, on which occasion he and his teen friends crammed sandwiches into their mouths, grabbed at the proffered cigarettes, and Toolis had his first experience of the acrid nature of snuff (Toolis 2017, pp. 248-49).

The liberal consumption of alcohol and tobacco, along with the playing of games and general riotous behavior, as described in Séan Ó Súilleabháin's 1967 Irish Wake Amusements, earned the wake the title of the 'Merry Wake'. It was this display of apparent merriment at the wake that caused great outrage among both visiting observers and the clergy. Etic observers, such as Samuel Hall (1841, vol. 1. p. 223), who were inclined to dismiss the custom as disrespectful, were, in fact, revealing their lack of understanding of the Irish culture. The Irish were 'celebrating life, not decrying the dead' (Toolis 2017, p. 252). In particular, the bawdy wake games were irksome to the clergy, intent on censoring earthly and carnal pleasures. As previously mentioned, over several centuries, there were many attempts by the Roman Catholic Church to stop these customs (Ó Crualaoich 1999, pp. 174-45; Ó Súilleabháin 1967, pp. 138-43). By the early 1800s a 'virtual curfew was imposed on young people, especially the unmarried, in an attempt to combat what the church considered the shameful and irreligious behaviors in which those attending the wakehouse indulged' (Ó Crualaoich, p. 175). During the latter part of the 20th century the tradition of 'waking the dead' went temporarily out of fashion and was replaced by the more modern custom of using funeral homes. For some, though, this was not sufficient closure. Kevin Toolis for example in the following, describes his feelings about the 'Western Death Machine' when his 26-year-old brother, Bernard, experienced a failed transplant and died in an English city hospital in the 1980s:

We never had a wake for Bernard: the Machine, the proceedings of dying in the city, the rupture of his death, the defeat of the transplant, had defeated us ... In the ruins, we did the other things too; a Mass, a funeral, a trip out to the city crematorium, a few hurried words at the head of the queue of hearses lining up outside, waiting their turn in the allocated slots of that day's burning ... We got on with living but it never felt right. Bernard was a wound we never bound up; a grave I could never close. (Toolis 2017, p. 112)

This emotional account reveals a key to the evolution of the wake; generic formulae were not enough for everybody, many needed a more personalized ritual on losing a loved one.

\section{Keen Within the Wake}

Did the keen really vanish from the mourning ritual, or did it, like many local customs and rituals among indigenous believers, merely go underground? Critics, who usually fell into one or another of the following categories, heavily denigrated the keen:

(1) Visitors who had stumbled on a funeral procession;

(2) those who visited a wake from curiosity and took an observer role; or

(3) Clergy who had a vested interest in stopping the practice as they perceived it as anti-Christian (Lysaght 1997, pp. 3, 4).

In the first and second instances, the observers were unaware of the context of the keen. In the third, they were violently opposed to it. Either way, the keen was not seen as a part of a broader ritual process but taken in isolation and condemned. Yet, despite the many attempts to annihilate it, the keen 
seemed to rise again in each generation, each new version reflecting societal and cultural/contextual shifts. This is a pattern that has continually repeated itself. For example, there were reports by the writer $O^{\prime} G$ of the keen dying out in the early 1830s. It is to be noted that $O^{\prime} G$ refers to past wakes and keening in terms of it having been a highly respected custom, being practiced by the noblest families. As a consequence of the denigration of the custom, it had become, even by his time of writing, debased.

Till about the middle of the last century, the custom was very generally adhered to in Ireland, as well in families of the highest condition, as among those of the lower orders; and many of the elegiac poems, composed on such occasions, have come down to us, ... Of late years, the custom has fallen greatly into disuse, and is now of rare occurrence, except in some very few old families, and among the peasantry, and with them it has now generally degenerated into a mere cry of an extremely wild and mournful character, which however, consisting of several notes, forming a very harmonious musical passage, approaches to a species of song, but is almost always destitute of words ( $\mathrm{O}^{\prime} \mathrm{G} 1833$, pp. 242-43).

If the wake games irked the clerical establishment, then the keen inflamed them, as it was considered an example of unbridled paganism that had no place in a Christian society. Over time, and amply aided by both alcohol (sometimes the only 'payment' a poor mourning family could afford), and ecclesiastical censure, (Ó Súilleabháin 1967, pp. 138-43), the identity of the keening women, the mná caointe ${ }^{2}$ (mraw kweentcha), became tarnished and by the middle of the nineteenth century. They were considered somewhat mercenary and dissolute (Ó Súilleabháin 1967, p. 141; Ó Buachalla 1998, p. 29). The practice barely survived but had changed over time and the absorption of Christianity was one agent of that change. This blend was noted in the 1930s in a report from Balla, Co. Mayo.

Blessed candles are placed in the hands of the dying person ... If the person was not very old women when entering and saying a few prayers joined hands beside where the corpse lay and caoined [sic] for several minutes. They were not really crying but wailing (Ó Maolanaigh 2016, vol. 0095, p.176).

Sidney Robertson Cowell also witnessed a ritual that synthesized the ancient practice with the accepted Christian ritual on the Aran Islands in 1956.

I heard the caoine going on in the house where the dead woman was lying, in the evening and before the coffin was taken to the church the next day. Except for two old women who came in to caoine before the service began, while there were yet only half a dozen people present, the service was seemly ... (Robertson Cowell in Ní Chongaile 2017)

It is somewhat ironic that the integration of Christian symbology into the pagan ritual possibly contributed to its survival, although not all, as the playwright John Millington Synge states in the following, appreciated this confluence of ideologies:

Before they covered the coffin an old man kneeled down by the grave and repeated a simple prayer for the dead. There was irony in these words of atonement and Catholic belief spoken by voices that were still hoarse with the cries of pagan desperation (Synge 1907).

\section{The Functions of the Wake}

The traditional Irish wake can be viewed as having included several functions that were interlocked. At a time of upheaval, the action of the wake provided structure, a primary function of ritual. Although not strictly linear, the 18th century wake contained the following elements:

- $\quad$ The corpse was laid out.

2 The noun for 'woman' in the Irish language is irregular, hence in the singular it is 'bean' (pronounced 'ban') but in the plural it is 'mná' (pronounced 'mraw' or 'minaw'). 
- The family keened over the corpse.

- Professional keeners took over.

- A stream of visitors came and went.

- The keening continued at regular intervals through the night (particularly when a new visitor arrived).

- The mourners stayed awake and participated in amusements and entertainment.

- There was periodic feasting and partaking of alcohol, tobacco, and snuff.

This pattern continued until the body was taken from the wake-house. Each one of these activities was heavily ritualized and, yet, they all fit together in a manner that passed the night or nights. This ordo appears to have survived in Ireland until the second part of the twentieth century.

On a pragmatic level the wake facilitated grieving in a very tangible manner, as follows:

- It was a powerful forum for emotional release, facilitated by two actors in the wake drama-the Borachán (Borachawn) and the Bean Chaointe (Ban Khweentcha), both of whose roles are discussed in detail below.

- It presented an occasion for the community to gather together, thus affirming and strengthening bonds. As Mooney wrote in 1888 (p. 270), 'a wedding or a funeral affords almost the only opportunity for a friendly gathering of neighbors to break in on the dul [sic] monotony of every-day life'.

- Community bonds were strengthened by the sharing of food, alcohol, snuff, and tobacco ${ }^{3}$. Samuel Hall's observation of wake customs in 1840's Munster reflected this, 'Close by it [the body], or upon it, are plates of tobacco and snuff; around it are lighted candles' (Hall 1841, p. 222). At that time, the tobacco was ritually smoked in special clay pipes, which were later buried. More than a century later the tobacco was contained in cigarettes but the ritual, as described by Kevin Toolis above (ibid., pp. 248-49), was similar. The wake also provided an opportunity for old bonds to be strengthened and new bonds to be formed (albeit many of these 'bonds' drew the disapproval of the clergy).

- The wake gathering offered an opportunity to celebrate the life as well as to mourn the passing of the deceased, thus it was also an occasion for celebration. This, indeed, is the main thrust of Seán Ó Súilleabháin's explanation for the somewhat festive atmosphere (Ó Súilleabháin 1967, p. 172). In fact, it reaffirmed life in the face of death.

- One of the most important elements was that the deceased was still included in that community. In fact, the deceased was the guest of honour. My mother once told me of a wake in Northern Ireland in the 1970s where the card game 'Bridge' was played and the corpse was propped up to hold a fan of cards to take the part of the 'dummy'. After all, this was a party for the deceased, so best to include him. This sort of action was based on two factors, honouring the deceased as a member of the community and fearing that he may wreak vengeance in his otherworldly state as a ghost if he was not honoured!

- Finally, it is considered by some, including this author, to have had a strong spiritual component where the soul of the deceased was safely shepherded to the Otherworld, principally through the work of the keening woman/women.... the keening woman, the bean chaointe, is the agent of the transition to the next life of the individual whose corpse lies at the heart of the wake assembly, and whose passing is ritually mourned all the way to the grave in the highly charged performance of the female practitioners of the caoin (Ó Crualaoich 1999). 
Transition is the keynote of death; transition not only for the deceased, but also for the entire community involved. Major transitions are often best navigated through ritual and the wake was a prime example of a community ritual that helped to affect that transition.

\section{Ritual Actors}

'Much of the power of the keen was in the emotional intensity of its performance' (Mc Laughlin 2017, p. 108).

If we view the wake as a drama, then the central character is the deceased and two of the main actors are the bean chaointe (keening woman) and the borachán, ${ }^{4}$ the 'organizer and director of the pranks and games of the wake assembly' (Ó Crualaoich in Donnelly et al. 1999, p. 191). It is these two who control and propel the action forward. The interaction between them intensifies the emotional outpouring, with the bórachán facilitating the laughter by orchestrating the more earthy wake games and the bean chaointe encouraging the expression of sorrow in a wailing lament. Both give license for emotional release but, in addition, each of these actors has a specific role that interfaces with, and compliments, the other. They are 'threshold people', who play a liminal role and reflect the ultimate liminality of the mourners. As Victor Turner points out, 'The attributes of liminality or of liminal personae ('threshold people') are necessarily ambiguous, since this condition and these persons elude or slip through the network of classifications that normally locate states and positions in cultural space' (Turner 1969, p. 95).

\subsection{The Borachán}

Acting in the role of 'fool' the borachán can break all the constraints of normal society. Ronald Grimes points to the liminality of the 'fool' that allows him to straddle thresholds while directing the action.

As the Latin etymology suggests, liminality is the process of passing over the threshold; it is a moment of boundary crossing. The idiot of the play is not only boundary crosser but also stage-manager (Grimes 2007, p. 211).

Ó Crualaoich notes that the term 'bórachán' is also 'applied to the 'joker' in card playing, and its use in relation to the 'joker' or master of revels at wakes is an extension of this meaning' (Ó Crualaoich 1999, p. 191 fn). The 'joker' in turn reflects the 'trickster', a character that is often evident in classical mythology.

Wherever the trickster appears, the premise is the same, the 'actors' put aside their daily identity to don a mask that permits them to have a foot both in this world and the (mythical) Otherworld. As Joseph Campbell, in his 1964 talk The Importance of Rites, comments: "Myths are the mental support of rites; rites, the physical enactment of myths" (Campbell 1972, p. 45). The bórachán has an important role to play at a death scene. After all, the central character (the deceased) is in the ultimate liminal state, that of literally passing between life and death, and this is being mirrored all around. The bereaved are in a liminal state, between roles (e.g., the wife has just become a widow, the child an orphan), and the bórachán is both mimetic and liminal in his own right. The bórachán is in the same category as what Grimes refers to as the Ritual Idiot, "...He pursues a meta-reality-a liminoid reality on the creative bound of society" (Grimes 2007, p. 217).

The function of the bórachán, then, could be seen as three-fold. Firstly, as Ó Crualaoich points out, he helps to propel the rite forward on a practical level by instigating and organizing the games and entertainment (Ó Crualaoich 1999, p. 193). Secondly, he introduces a mythic level. At this level, humans are often able to integrate that which challenges them on other planes. Joseph Cambell points

4 'The term 'borekeen' as used by John Prim (1852) may be assumed to be a transliteration of a diminutive form of the Irish, 'a bow-legged person', a person with crooked feet'. (Ó Crualaoich fn op. cit) 
out that it is particularly important for young people to participate in the myths and rites of their social group 'to accord with [their] social as well as natural environment ... ' (Campbell 1972, p. 45).

Thirdly, as Ó Crualaoich indicates, the bórachán affirms the community,

...his role is that of the social order itself personified. In the person of the 'borakeen' and of his willing helpers and henchmen (the 'hardy boys' and 'prime lads'), the community displays its vitality and continuity in the face of mortally threatening contact with the supernatural realm (Ó Crualaoich 1999, p. 193).

Ironically it was these misunderstood functions of the bórachán that drew the wrath of the clergy and the censure of visiting reporters who, not being from the Irish culture, did not understand what they were witnessing. In their belief systems, prayer and restrained tearfulness were considered more appropriate and respectful at a funeral and there was no space allowed for laughter; neither was there space allowed for hysterical crying, never mind the combination.

The role of the bórachán, then, is part of the support system that facilitates the departure of the deceased from the community. This is an important stage in the rite and it paves the way for the other liminar of the funeral obsequies-the bean chaointe (keening woman), as she shepherds all present towards the Otherworld, where the deceased will be received and the mourners cry their final farewell from the human world.

\subsection{The Bean Chaointe}

In talking about his brother Bernard's passing in the 1980s, (see above) Kevin Toolis described the spontaneous outpouring of grief that occurred in his home on hearing of the death, as follows:

I rushed back to my parents' house into the maelstrom of my keening mother, sisters and Bernard's wife. The immediacy of his death was a convulsion, a physical pain that gripped at your chest, smothering then bursting out in heaving sobs, rivers of tears, panic. The cries of the women, and my own, soared around an ordinary suburban sitting room. The keening was a primeval scream, a calling out of the agony of death, an eruption of despair, tenderness, fear, love, loss and pain (Toolis 2017, pp. 108-9).

This may seem at odds with his earlier statement regarding the ineffectiveness of the 'Western Death Machine' (see above). This spontaneous family mourning, however, was more organic than ritualized and if we look at the following elements of the wake (see 'Functions of the wake' above), we notice that, although the first stage of the traditional keen was a spontaneous expression of grief by the family, it was:

(a) Performed over a corpse (Lysaght 1997; Ó Madagáin 2005), and

(b) fully ritualized by the formalized keening of professional keeners over the body, within the context of the wake.

Neither of these elements were present in the case of Bernard Toolis. A disconnect occurs when a ritual is not completed. Arnold van Gennep's theory of the tripartite nature of a separation rite could well apply here ${ }^{5}$. Toolis stated that, in his brother's case, 'Bernard was a wound we never bound up; a grave I could never close' (Toolis 2017, p. 112). I would suggest that this was because the ritual of grieving, in his case, was not completed and the author remained in the liminal (in-between) state. Had there been a wake, he would probably have had more closure, as he did in the case of his father's wake (the subject of his 2017 book). In the traditional Irish wake, the process of keening

5 Van Gennep positis that a separation rite has three stages, as follows: Pre-liminal (separation), liminal (transition), and post-liminal (incorporation) (van Gennep 1909, p. 21.). 
would have moved from the searing spontaneous family reaction through the ritual of the wake with the professional keeners, led by the bean chaointe (keening woman), to a crescendo at the graveside and then to subsidence as the ritual closed. The professional mourners who were hired for such occasions, were highly proficient at their trade - creating a cathartic environment which helped release the grief of all present and satisfy the deeply held belief that the deceased deserved a good 'send-off', a premise eloquently explained by Seán Ó Súilleabháin in his Irish Wake Amusements (Ó Súilleabháin 1967, pp. 170-74). Men were sometimes known to perform the keen (Hennigan 2012, p. 72), but the keeners were usually women who worked either solo or in small groups. According to Breandán Ó Madagáin, the latter was more desired as 'to be keened by gol mná aonair ("the cry of a lone woman") is still remembered in the Gaeltacht (Gwayltocht) ${ }^{6}$ as a great indignity to the deceased' (Ó Madagáin 1982, p. 313). Although an etic account, Samuel and Mrs. Hall's account of the wake they witnessed in the 1840 s is invaluable in terms of the observer detail and gives us a visceral description of the process of Keening,

The women of the household range themselves at either side, and the keen at once commences. They rise with one accord, and, moving their bodies with a slow motion to and fro, their arms apart, they continue to keep up a heart-rending cry. This cry is interrupted for a while to give the ban caointhe (the leading keener), an opportunity of commencing. At the close of every stanza, the cry is repeated....and then dropped; the woman then again proceeds with the dirge, and so on to the close (Hall 1841, vol. 1, pp. 222-23).

Over time, the perception of the keeners changed, from women who commanded respect and awe to women of dissolution. Angela Partridge (Partridge 1980-1981, pp. 29-31) paints a picture of the bean-chaointe as barefoot and bareheaded, with hair flying and clothes in disarray, often torn or ragged. The Halls, similarly, describe the bean-chaointe, whom they witness as having "long black uncombed locks [which] were hanging about her shoulders... Her large blue cloak was confined at her throat; but not so closely as to conceal the outline of her figure, thin and gaunt, but exceedingly lithesome" (Hall 1841, vol. 1, p. 227).

They also noted that the bean-chaointe was normally an "aged woman" but if she was younger "the habits of her life make her look old" (Ibid., p. 226). There was a certain rhythm to the bean-chaointe's performance and she used motion to dramatic effect, as the account below from the Halls demonstrates. In it, as follows, they describe how, as they enter the wake-house, she is sitting by the corpse; then she rises:

When she arose, as if by sudden inspiration, first holding out her hands over the body, and then tossing them wildly above her head, she continued her chaunt in a low monotonous tone, occasionally breaking into a style earnest and animated; and using every variety of attitude to give emphasis to her words, and enforce her description of the virtues and good qualities of the deceased (Hall 1841, vol. 1, p. 227).

(The Halls observed that the bean-chaointe would cease each time a new mourner came into the wake-house and then begin the process again.)

The only interruption which this manner of conducting a wake suffers, is from the entrance of some relative of the deceased, who, living remote, or from some other cause, may not have been in at the commencement. In this case, the ban caointhe ceases, all the women rise and begin the cry, which is continued until the newcomer has cried enough (Ibid., pp. 222, 224).

In their own ways, both actors are the personifications of a psychopomp-a leader of souls (Cowan 1993, pp. 61-62). The role of psychopomp that these two characters embody is only mentioned in

6 Irish—speaking areas. 
passing here but, basically, the borachán represents the clown/trickster, who leads the way into the Otherworld, and the bean chaointe straddles the two worlds of the living and the dead.

In addition, scholars such as Patricia Lysaght (1986, pp. 49, 64) and Gearóid Ó Crualaoich (in Donnelly et al. 1999, p. 192) draw parallels between the bean chaointe and the dreaded bean sí (banshee). In Irish folklore, the bean sí is an otherworldly harbinger of death who attaches herself to certain families. She is often reported as wailing before a death in the family and is thus much feared as she is considered to be a bad omen. Patricia Lysaght did an excellent exploration of the bean sí in her 1986 book, The Banshee, The Irish Supernatural Death Messenger, where she draws attention to the juxtaposition between the two figures of the bean si and the bean chaointe. No doubt, the evocative picture of the keening women sitting on top of the coffin ${ }^{7}$ and wailing as the funeral procession weaves towards the graveyard (see also Ó Súilleabháin 1967, p. 143, Ó Crualaoich in Donnelly et al. 1999, p. 182), contributes greatly to the confusion between the two figures.

Some scholars see one as the reflex of the other, further defining the keening woman's identity as being connected with the Otherworld. As 9puts it in the following:

I suggest that we view the bean chaointe at the wake as a flesh-and-blood reflex of the supernatural female sovereign who rules over the Otherworld and into whose domain the deceased is now to be translated. In this light the bean chaointe is the (human) structural adjunct of the banshee.... (ibid., p. 192).

Considering that one of the functions of the wake is that it is an important community event, where, as Gearóid Ó Crualaoich points out, social order is re-established after the rupture of death, the bórachán and the bean chaointe stand on either side of that event. Ó Crualaoich though, also notes the more profound role of each, as follows:

If the 'old man' or 'borekeen', who is said to be well known in each district as an organizer and director of the pranks and games of the wake assembly, is the agent of that socially cathartic chaos out of which a renewed social order can emerge, then the keening woman, the bean chaointe, is the agent of the transition to the next life of the individual whose corpse lies at the heart of the wake assembly and whose passing is ritually mourned all the way to the grave in the highly charged performance of the female practitioners of the caoin (ibid., pp. 191-92).

\section{Music of the Keen}

Perhaps the most important thing to remember about the music of the keen is that it varied on each occasion it was sung. Whether it was performed by family or by professional keeners brought in for the occasion, there was a tradition in which the keeners worked and, according to Angela Partridge, they drew on 'the same body of motifs and diction',

The metre they used is called rosc-short lines of two or three stresses, linked by Ó Madagáin, end-rhyme and arranged in stanzas of uneven length...The short lines and long stanzas give the caoineadh a sort of headlong, breathless style, which was used very effectively by some of the more talented mná caointe (Partridge 1980-1981, p. 27).

PW Joyce gives an example in his 1873 'Ancient Irish Music', which shows how the lament vocable 'Ochone' was scanned to the melody (Joyce 1873, p. 60).

Both Rachel Bromwich (1948) and Seán Ó Coileáin (1988) give excellent analyses of the structure of the caoineadh by extracting specific characteristics that seem to be common to the genre. Brendán Ó

7 There is an excellent illustration of this in Barrow (1836), published in Hennigan (2012, p. 71). 
Madagáin (1982, pp. 312-13) has identified three components or motifs which help further analyze the form, as mentioned in the introduction of this essay. These three motifs are the following: The salutation (introduction), the dirge (verse), and the gol (cry). Ó Madagáin goes on to note that the melody is very different from the usual Irish style. He also comments on the speed at which the keen was delivered, as follows:

... indeed it can only be described as a chant, and that of a simple unornamented kind, reminiscent of Latin Plainsong. There is no musical metre, complete freedom being given to the language with several syllables and sometimes-whole phrases being sung to the same note... The lively speed at which it was sung (quaver $=208$ ) may seem surprising for a dirge, but the other extant examples are equally as fast... (Ó Madagáin 1982, p. 314).

One of the best surviving examples of this three-part structure is probably the 'Caoinan or Irish Funeral Song' stored at the Royal Irish Academy, Dublin. This is a manuscript that was reportedly transcribed in 1782 (Beauford 1790-1792, pp. 46-51) and which illustrates the keen's tri-partite structure and the vocal ability that was necessary to perform it ${ }^{8}$. Brendán Ó Madagáin claims that many of the lines of the keen on Beauford's manuscript (which Beauford claimed to have 'obtained from an old female keener'), harks back to an older manuscript as ' almost all the lines he uses were printed by Edward Lhuyd eighty two years before in his Archaeologia Britannica (Lhuyd 1707), p. 309)' (Ó Madagáin 1982, p. 329, n. 11).

There are three recorded keens from the mid-twentieth century (already referenced in the introduction of this essay) which, although recorded outside the context of the wake and therefore mimetic or remembered rather than spontaneous, give us some idea about the sound of the keen.

It is interesting to note that of the three, Kitty Gallagher's 1951 recorded keen from Donegal (Ní Gallchóir in Lomax 1998, tr. 28) is more focused on the gol (the cry) than the Keens sung by the unnamed Aran Female Singer $(1957$, tr. 9) and by Bridget Mullin $(1957$, tr. 20) recorded by Sydney Robertson Cowell in 1957. These two examples are more reminiscent of the cronán, which is described by Eugene $\mathrm{O}^{\prime}$ Curry as a 'purring,' beginning 'in the 'chest or throat on a low key and rising gradually to the highest treble' ( $\mathrm{O}^{\prime} \mathrm{C}$ urry 1873 , vol. 3, p. 374). Kitty's is more melodic and placed in the singing register of the voice while the two Aran Island Keens have a more chant-like sound in that they are closer to the speaking register (Mc Laughlin 2018a, Doctoral Thesis, p. 50).

There could be several reasons for this-not least that there was a considerable age-difference between the older Aran women and the younger Gallagher, but it is also worth considering the context. Gallagher's is entitled 'Keen for a dead child' whereas there is no such specific information attached to the other keens. The age and status of the deceased tended to reflect the depth of the mourning. The examples do suggest, however, the scope of the lament.

\section{Spiritual Function}

There is no doubt that many subscribe to the spiritual nature of the keen, in addition to its cathartic and community-building functions. It is also possible that the keen that has survived is but a reflection of a greater ritual, which, like many monuments in Ireland, became chipped away with time. In referring to a keen transcribed for their travelogue, Samuel Hall commented,

This keen is very ancient and there is a tradition that its origin is supernatural, as it is said to have been first sung by a chorus of invisible spirits over the grave of one of the early Kings of Ireland (Hall 1841, pp. 227-28). 
Brendán Ó Madagáin (2005, p. 151) posits that the keen originally 'had a religious function-perhaps the validation of ritual-as it clearly belongs to the heroic tradition which as hero-worship was part of a religious cult.' In his 1989 paper ('Gaelic Lullaby: a Charm to Protect the Baby?') Ó Madagáin also draws parallels between lullabies and keens (Ó Madagáin 1989, p. 33) and further suggests that lullabies had an incantatory quality (ibid., p. 36). This could also be said of the keen. Building on the work of Ó Madagáin, I suggested, in my 2018 doctoral thesis, that the keen could have been part of a much more extensive ritual that marked the circle of birth and death. It was commonplace that the mid wife (who brought in life) and the bean chaointe (who brought out life) were one and the same person and who may well have used the same ceremonial vocables (Mc Laughlin 2018a, p. 205). As briefly mentioned above, it is also possible that the borachán and bean chaointe took the role of pyschopomps and were instrumental in ushering the soul of the deceased into the Otherworld. The concept of 'psychopomp' is a shamanic one and Angela Partridge (1983, p. 93) evidences comparisons between the bean-chaointe and a shaman. Fascinating as the shamanic connection is, that discussion leads into an area of magic ritual outside the scope of this essay and must be saved for another paper.

\section{Current State of Affairs}

It is remarkable that, despite both direct and indirect opposition, the ritual of the wake with the keen at its center is still a feature of Irish life in the 21st century, albeit that it has been, like the Gaelic culture in which it evolved, marginalized. Perhaps it is not surprising then that in Gaelic speaking areas, called An Ghaeltacht (The Gayltokht), the ritual is found at its most intact. Shadows of it, though, have never left the island and the wake, although a watered-down version of that which had prompted censure, has remained a facet of the Irish Catholic culture, both South and North. Presently, there are no hired keeners and plates of tobacco and snuff being passed around or wild bawdy games being played, but the vestiges have (and do) survived. The community comes in to visit the deceased laid out in the coffin and eat and drink in his/her presence as a mark of inclusion-the corpse is still among them and will be until the coffin lid is closed and another stage of the ritual begins.

Although the traditional keeners were considered professionals and were hired for the occasion, the keeners of the 20th and 21st centuries are more likely to be family members who are preserving and drawing on traditional keening practice. This would sometimes include the singing of songs either as keens or in addition to the traditional keen. For example, Breandán Ó Madagáin cites Seaghán Bán Mac Grianna from the Donegal Gaeltacht,

They used to keen and they used to sing (songs) ... Of course, singing and keening were very closely connected, and there was never a wake in the old days that would not have a song being performed. And I heard my own mother saying that she saw a woman putting her son into the coffin, a young boy, and she singing (as distinct from keening) and shedding tears (Ó Madagáin 1985, p. 155, n. 81).

Ó Madagáin (1982, p. 312) also refers to extant recordings of Gaeltacht keens as providing only 'a faint echo of a tradition recalled by individuals long after it has ceased to have had that continual community usage which alone would maintain its vigor and fullness, either musically or linguistically' (ibid.). Still, it seems to this author that the shadows of the old ritual have extended their influence and the keen has not so much died out as morphed into a ritual adapted to a more modern way of life, while maintaining its essential elements.

This author had the privilege of recording an eyewitness account of a Gaeltacht funeral as recently as the early 2000s and the account gave the impression of a very organic ritual, arising from within a community situation. The occasion was the funeral of a young man who was mourned at the graveside by his mother and two other females, possibly his aunts. My informant (who is referred to under the pseudonym of MK) was a witness to the mourning at the graveside. 
... there was three chairs brought to the graveside where his mother sat on one and two other women-now they were, what I found unusual was that they were very close together, literally thigh rubbing off thigh and they started to sing. Now the songs were in Irish, they were not anything I'd ever heard before. While they sang it was quite emotive, it was ... they sounded like songs that he would have known or something, definitely there was connotation with the family, but the three nearly sang as one ... they were all crying. I remember the way they sat. They kind of sat with their legs together and they had their hands crossed across their thighs [demonstrates] the three of them were the same. Their lower body didn't move but their upper body did, it was like as if they were kind of swaying, now it wasn't anything very pronounced ... this is right at the grave, where literally the tips of their feet are at the grave and the three chairs very close together, really tight and people were just kind of all around.

(MK went on to describe the eerie silence that descended on the large group of mourners.)

... there wasn't a sound anywhere, all you could hear was the sound of the sea, and the sound of wind, but other than that nobody spoke, nobody said anything, people weren't, you know as you would see at funerals I think in these kind of moments, people at the back maybe having a chat [dramatic pause]—nothing. Everyone was just focused on it hmm [pause] and I don't think it was kind of a thing of respect—of 'we shouldn't talk when someone was singing' - I think it was just, people were kind of - it was like [short laugh] if you used the metaphor of the rabbit looking into the headlights; everyone was just glued to it you know. It was like an enchanted moment, just for that four or five minutes and then [short pause] it was gone. (MK personal interview in Mc Laughlin 2018a, pp. 189-92).

If this effect occurred in a reduced ritual, we can only begin to imagine the power of the ritual in its fullest capacity as suggested by Ó Madagáin above!

One other interesting thing to consider though is how not only Irish history and mythology play into the ritual, but also the very landscape. Whether this interplay between landscape and tradition suggests that the keen is an appropriate ritual for Ireland alone or encapsulates a universal piece of the human experience deserves another paper, but it seems appropriate to put this in context and let MK, a living witness to this amazing ancient ritual, describe what he meant by 'an enchanted moment', as follows:

... what I would call 'an enchanted moment', I think, the landscape has to feed into it as well, maybe you're looking at things that you feel; well this makes up an enchanted moment. You have the water, the waves crashing, you have a very wide-open treeless scrub type of a landscape, just rolling hills and bleak, barren, rocky. Uh, and I think, for the few minutes it lasted, it was like as if everything else went out the door, you know, it was like ... There was nearly like a crossover between [short laugh] the normal everyday life and kind of into the supernatural a small bit. It was like as if you were just standing on the cusp of it, where, there was nowhere to look forward, nowhere to look back; you're just in that moment.

(MK op. cit.)

\section{Conclusions}

Within its context, that of the wake and funeral, the ancient Irish lament practice of keening, with its roots in pre-Christian Ireland, marked the rite of the passage of death. By the middle-ages Christian practice had become dominant and the keen was marginalized, almost to the point of extinction. For example, Padraigín Ní Uallacháin refers to a professional keener, Margaret Modartha Kelly, 'the last known keening-woman in southeast Ulster who died in 1926' (Ní Uallacháin 2005, p. 140). The reports that we have of keening on the Aran Islands in the 1950s from Sidney Robertson Cowell, or the 
contemporary report from MK in the 21st century, show that the practice has not actually died but the modern practices are merely a reflection of this ancient tradition, while still placing the custom firmly within the context of the wake and funeral of a loved one, giving it an air of mystique and elusiveness.

Death is a profound event which elicits a variety of responses. In her chapter about the music chosen for the funeral of Princess Diana, Helen Hickey noted the following:

$\ldots$ in death she divided the public into those who grieved openly and unashamedly and those who thought that this type of open public grief was excessive and insincere (Dell and Hickey 2017, p. 167). ${ }^{9}$

Reactions of the bereaved can often be unpredictable, sparking further reaction in other mourners so that the course of the emotional release takes unexpected turns.

From personal experience, this author can verify that a fixed religious ceremony is not always sufficient to address the primal feeling experienced on the loss of a close relative or companion. At my mother's wake in 1995, the spiritual aspect was pre-dominantly Catholic, with the priest leading rosaries over the coffin, but for me it was not enough, as I described in a blog written for the Australian Centre of Excellence over twenty years later.

Thirty-six hours after my mother had died the priest came to the house and, surrounded by our community of family and neighbours, we again chanted the rosary as he walked around the open coffin sprinkling my mother's lifeless body with holy water. The coffin lid was closed in preparation for her journey to church and burial. It was at that point that the reality hit me like a thunderbolt. I had been managing for a week; managing her fears about death, managing my family's hysteria and abject grief, managing my own feelings-and all of this without sleep. Her death and the period when she was waked had a very surreal quality, but I will never forget the sound of that lid sealing the coffin and in that instance realising she had gone from this life. I felt a wail begin in the centre of my stomach; it was uncontrollable as it came through my body and out of my mouth in a dis-embodied shriek of unbridled grief. My head was telling me that this was 'not respectful'. This was the construct that had been laid on Irish Catholics who had keened for their dead in the centuries anterior to its dwindling. I did not wish to be disrespectful but I just could not stop screaming. (Mc Laughlin 2018b, blog).

Customs may change and beliefs may shift, but the essential need of humans to express emotional pain at different levels will always remain. The Irish keen within the wake seems to have allowed for such possibilities in its malleable nature so that each generation could find their own point of resonance. Perhaps therein lies the secret of its survival in Ireland.

Funding: Some of this article is based on author's $\mathrm{PhD}$ research which was partially funded by the Irish Research Council, Government of Ireland Postgraduate Scholarship 2016-17 Project ID: GOIP/2016/1149.

Conflicts of Interest: The author declares no conflict of interest.

\section{References}

Aran Female Singer. 1957. Caoineadh na Marbh. In Songs of Aran: Gaelic Singing from the West of Ireland. [CD] tr. 19. Washington: Smithsonian Folkways Recordings FM4002.

Barrow, John. 1836. A Tour Round Ireland, Through the Sea-Coast Counties, in the Autumn of 1835. London: J. Murray. Beauford, William. 1790-1792. Caoinan: Or Some Account of the Antient Irish Lamentations. The Transactions of the Royal Irish Academy. Dublin: Royal Irish Academy, vol. 4, pp. 41-54. Available online: http: //www.jstor.org/stable/30078681 (accessed on 22 November 2017).

9 See chapter 1 by Samuel Curkpatrick (Dell and Hickey 2017) which addresses the emotional power of music as mourning in indiginous Australian tribe. 
Bromwich, Rachel. 1948. The Keen for Art O'Leary, Its Background and Its Place in the Tradition of Gaelic Keening. Dublin: Éigse 5.2, pp. 236-52.

Campbell, Joseph. 1972. Myths to Live By. New York and London: Viking Press.

Cowan, Tom. 1993. Fire in the Head: Shamanism and the Celtic Spirit. San Francisco: Harper.

Dell, Helen, and Helen Hickey, eds. 2017. Singing Death: Reflections on Music and Mortality. London and New York: Routledge/Ashgate.

Fleischmann, Aloys. 1998. Sources of Irish Traditional Music c. 1600-1855. New York and London: Garland Publishing.

Grimes, Ronald. 2007. Beginnings in Ritual Studies, 3rd ed. Columbia: University of South Carolina Press.

Hall, Samuel. 1841. Ireland, Its Scenery and Character. London: Howe and Parsons, vol. 1. Available online: http://www.askaboutireland.ie/aai-files/assets/ebooks/50-52\%20Ireland/50\%20Ireland\%201.pdf (accessed on 27 March 2019).

Hennigan, Julie. 2012. Literacy and Orality in Eighteenth-Century Irish Song. Poetry and Song in the Age of Revolution. Available online: www.ebook777.com (accessed on 8 May 2016).

Joyce, Patrick Weston. 1873. Ancient Irish Music. Dublin: McGlashan and Gill; London: MarshallSimpkin, Edinburgh: John Menzies, Available ITMA (Irish Traditional Music Archive). Available online: https: //www.itma.ie/digital-library/text/ancient-irish-music-joyce (accessed on 27 March 2019).

Lhuyd, Edward. 1707. Archæologia Britannica Volume 1. Oxford: Ashmolean Museum. Available online: https://archive.org/details/archaeologiabrit00lhuy/page/n3 (accessed on 27 March 2019).

Lysaght, Patricia. 1986. The Banshee, the Irish Supernatural Death Messenger. Dublin: O'Brien Press.

Lysaght, Patricia. 1997. Caoineadh Os Cionn Coirp: The Lament for the Dead in Ireland. Folklore 108: 65-82. Available online: http://www.jstor.org/stable/1260709 (accessed on 5 November 2013).

Mc Laughlin, Mary. 2017. Moving Between Worlds. In Singing Death: Reflections on Music and Mortality. Edited by Hellen Dell and Hellen M. Hickey. London and New York: Routledge/Ashgate, pp. 107-18.

Mc Laughlin, Mary. 2018a. Songs between Worlds: Enchantment and Entrapment in the Irish Otherworld Song Tradition. Ph.D. Dissertation, University of Limerick, Limerick, Ireland.

Mc Laughlin, Mary. 2018b. 'Keening-A Mourning Ritual for Our Time?' blog. Histories of Emotion from Medieval Europe to Contemporary Australia. Melbourne Australian Research Council's Centre of Excellence for the History of Emotions. Available online: https://historiesofemotion.com/2018/03/18/keening-a-mourningritual-for-our-time/ (accessed on 19 March 2018).

Mooney, James. 1888. The Funeral Customs of Ireland. In Proceedings of the American Philosophical Society. Washington: American Philosophical Society, vol. 25, pp. 243-96. Available online: http://www.jstor.org/ stable/983061 (accessed on 16 August 2017).

Mullin, Bridget. 1957. 'Caoineadh na Marbh'. In Songs of Aran: Gaelic Singing from the West of Ireland. [CD] tr. 20. Washington: Smithsonian Folkways Recordings FM4002.

Ní Chongaile, Deirdre. 2017. The Yank with the Box: Sidney Robertson Cowell collects music in 1950s Ireland. Paper presented at International Council for Traditional Music 44th World Conference, Limerick, Ireland, July 13-19.

Ní Gallchóir, Cití. 1951. 'Keen for a Dead Child' in Lomax: Ireland. In World Library of Folk and Primitive Music. [CD] tr. 27 (tr. 28 in Liner Notes). Nashville: Rounder Records Corp, vol. II.

Ní Uallacháin, Pádraigín. 2005. A Hidden Ulster. Dublin and Portland: Four Courts Press Ltd.

Ó Buachalla, Breandán. 1998. An Caoine agus An Chaointeoireacht. Dublin: Criterion Press.

Ó Coileáin, Seán. 1988. The Irish Lament: An Oral Genre. In Studia Hibernica \#24. Dublin: St. Patrick's College, Dublin City University, pp. 97-117.

Ó Crualaoich, Gearóid. 1999. The Merry Wake. In Irish Popular Culture 1650-1850. Edited by James S. Donnelly and Kerby A. Miller. Dublin and Portland: Irish Academic Press.

Ó hÓgáin, Daithí. 2002. The Celts a History. Cork: Collins Press.

Ó Madagáin, Brendán. 1982. Irish Vocal Music of Lament and Syllabic Verse. In The Celtic Consciousness. New York: George Braziller, pp. 311-32.

Ó Madagáin, Brendán. 1985. 'Functions of Irish Song in the Nineteenth Century' Béaloideas, Iml. Dublin: The Folklore of Ireland Society, vol. 53, pp. 130-216. Available online: http://www.jstor.org/stable/20522261 (accessed on 8 October 2014). 
Ó Madagáin, Brendán. 1989. Gaelic Lullaby: A Charm to Protect the Baby? In Scottish Studies. Edinburgh: University of Edinburgh Press, vol. 29, pp. 29-36.

Ó Madagáin, Brendán. 2005. Caointe Agus Seancheolta Eile-Keening and Other Old Irish Musics. Ireland: Clo Iar-Chonnachta Teo.

Ó Maolanaigh, P. 2016. 'Funeral Customs' National Folklore Archive, the Schools Collection. vol. 0095, p. 176. Available online: https://www.duchas.ie/en/cbes/4427833/4348527/4435514 (accessed on 27 March 2019).

Ó Súilleabháin, Seán. 1967. Irish Wake Amusements. Dublin: Mercier Press.

O'Curry, Eugene. 1873. On the Manners and Customs of the Ancient Irish. London: Williams and Norgate; Dublin: Fowler, vol. 3.

O'G. 1833. The Irish Funeral Cry. The Dublin Penny Journal 1: 242-44. Available online: http://www.jstor.org/stable/ 30002710 (accessed on 26 May 2015).

OED. 2019. Oxford English Dictionary. Oxford: Oxford University Press.

Partridge, Angela. 1980-1981. Wild Men and Wailing Women. Dublin: Eigse, vol. xviii, pp. 25-37.

Partridge, Angela. 1983. Caoineadh Na dTrí Muire. Dublin: Dundalgan Press.

Ross, Annie. 1982. Material Culture, Myth and Folk Memory. In O' Driscoll the Celtic Consciousness. New York: George Braziller, pp. 197-216.

Synge, John Millington. 1907. The Aran Islands. Reprint 1992. London and Dublin: Penguin Twentieth Century Classics.

Toolis, Kevin. 2017. My Father's Wake: How the Irish Teach Us to Live, Love and Die. London: Orion (Weidenfield and Nicholson).

Turner, Victor. 1969. The Ritual Process. Chicago: Aldine Publishing Company.

van Gennep, Arnold. 1909. Les Rites de Passage, the Rites of Passage. Translated by Monika B. Vizedom and Gabrielle L. Caffe. Chicago: University of Chicago Press.

(C) 2019 by the author. Licensee MDPI, Basel, Switzerland. This article is an open access article distributed under the terms and conditions of the Creative Commons Attribution (CC BY) license (http://creativecommons.org/licenses/by/4.0/). 